\title{
POLITICS PERCEPTION AND SATISFACTION AMONG SCHOOL TEACHERS: THE MODERATING ROLE OF EMOTIONAL INTELLIGENCE
}

\author{
James R \\ Department of Human Resource Management \\ University of Jaffna \\ robinson435@gmail.com \\ KUSVURLFIGIRUD0000-0001-9782-8442
}

\begin{abstract}
Emotional intelligence has become a fundamental construct in recent management researches. However, no detailed study available that investigate the effect of Emotional intelligence (EI) on the influence of perceived organizational politics on work outcomes of teachers. This study fills this gap by investigating the moderating role of EI on the relationship between perceived organizational politics and satisfaction among school teachers. The study was conducted with 276 school teachers in the northern part of Sri Lanka, and the data were analyzed employing appropriate statistical tools. This study explored that perceived organizational politics had a significant and negative impact on satisfaction among school teachers. Also, this study disclosed that EI moderates the relationship between perceived organizational politics and satisfaction. The results show that higher EI levels lead to a weaker relationship between politics and satisfaction, while lower levels of EI leads to a stronger relationship between politics and satisfaction. This study contributes to both theory and practice by investigating the influence of organizational politics on satisfaction among school teachers in Sri Lankan context which is a group ignored in the previous studies and introducing teachers' EI as moderating variable in the said relationship.
\end{abstract}

Keywords: emotional intelligence; organizational politics; perception; satisfaction; teachers. 


\section{Introduction}

For many decades, employees' job satisfaction has been a critical construct among research scholars as it produces significant positive outcomes to both employees and the organization. Satisfied employees are highly motivated, engaged and committed to their organization, and they perform better in the workplace. Also, the organization with more satisfied employees tend to be more effective than organizations with less satisfied employees. Therefore both organization and employees are very concern about employees' satisfaction in the workplace. However, the importance of teachers' satisfaction has been overlooked. Satisfied teachers are less vulnerable to strain and burnout, experience a high level of wellbeing, offer better learning support to their students, highly committed to their organization, and intend to stay at their profession (Blömeke et al., 2017; Liang \& Akiba, 2017; Klassen \& Chiu, 2011). Though a large number of studies conducted to identify the influence of personal and organizational level variables among business employees, there is a limited number of studies are that investigates the influence of personal and organizational variables on teachers' job satisfaction.

A large number of studies explored the existence of politics in an organizational setting (Kacmar \& Baron, 1999; Ferris et al. 2002; Landells \& Albrecht, 2019). Perceived organizational politics inherently represent the dysfunctional side of the organization (Ferris \& Judge 1991). The harmful, destructive, and adverse effects of organizational politics on work outcomes such as satisfaction, stress, burnout, employees turnover, work engagement, employee well-being and organizational commitment have been Well-documented in management and organizational behaviour literature (Asrar-ul-Haq et al., 2019; Chang et al., 2009; Landells \& Albrecht, 2019; Vigoda-Gadot \& Talmud, 2010). Christiansen et al. (1997) noted that some individual-level variables could influence the negative consequences of organizational politics. Many scholars have attempted to find out the variables mitigating the negative consequences of organizational politics on employee's satisfaction. Few studies assessed the moderating effect of some personal and dispositional variables such as self, efficacy, locus of control, positive framing on the relationship between politics perception and work outcomes. They found that individual who possess some level of control over the work environment (Ferris et al., 1996) and understanding the underlying rationale for organizational behaviour (Ferris et al., 1994) are less likely to report the adverse effect of organizational politics. 
Emotional Intelligence (EI) is an individual's ability to monitors one's own and others' feelings and emotions, to discriminate among them and to use this information to guides one's thinking and actions (Mayer et al., 2000). The individual with high EI can motivate oneself and persist in the face of frustration, to regulates one's moods and keep distressed from swamping the ability to think, empathize and to hope (Goleman, 1995). According to the Job Demand Resource (JD-R) model the characteristics of the work environment are segregated either as job resources or job demands (Bakker \& Demerouti, 2007; 2014). The job resources lead to positive psychological and organizational outcomes, while job demands lead to adverse psychological and organizational outcomes. Organizational politics as demand can lead to adverse psychological and organizational outcomes such as dissatisfaction and disengagement; however, EI as a personal resource can reduce the adverse effect of organizational politics.

Many studies related to organizational politics and its behavioural and attitudinal outcomes have been conducted in business organizations and western cultural context. However, there is a lack detailed study found that attempt to find out the influence of organizational politics and EI on satisfaction among teachers. Remarkably there are no studies related to organizational politics and its consequences among school teachers in Sri Lankan context. Therefore, this study aims to investigate the influence of organizational politics on job satisfaction among school teachers and the effect of emotional intelligence on the relationship between politics perception and satisfaction. This study contributes to both theory and practice by investigating the influence of organizational politics on satisfaction among school teachers in Sri Lankan context which is a group ignored in the previous studies and by being the first study that introducing teachers' EI as moderating variable in the said relationship.

\section{Literature Review and Hypotheses Development}

\section{Organizational politics}

The organization is a market where various individuals engage in a variety of dealings, each seeking promising gain on their investment (Rusbull et al. 1996). Individuals and groups employ different strategies to increase their benefits and promote and protect their self-interest in the workplace (Kacmar \& Baron, 1999; Yusof et al., 2018). Therefore, politics has become a fact of organizational life (Akanbi \& Ofoegbu, 2013; Gandz\& Murray, 1980). 
One of the very first definitions of organizational politics offered by Lasswell (1936) labels politics as "who gets what, when and how". According to Pfeffer (1992), politics is the study of power in action. Farrell and Petersan (1992) describe political behaviour in organizations are "those activities that are not required as part of one's formal role in the organization but that influence or attempt to influence, the distribution of advantages and disadvantages within the organizations". Kacmar and Baron (1999) similarly argued that organizational politics "involves actions by individuals that are directed toward the goal of furthering their own self-interest without regard for the well-being of others or their organization" (p. 4).

According to Saiyadain (2003) form of political behaviours includes bypassing a chain of commands, withholding information, spreading rumours, leaking confidential information, lobbying, using pressure tactics, "fixing" people, and sabotaging. Many studies focused on the way employee's perceived organizational politics and its consequences. In this respect, Ferris et al. (1989) proposed a model that explains how organizational politics works in the workplace. Much of the works related to the perception of organization politics revolves around his model. Consequent studies have confirmed the essential elements of the model and documented the negative effect of perceived organizational politics on employees work attitudes (Asrar-ul-Haq et al., 2019; Chang et al., 2009; Cropanzano et al., 1997; Ferris et al., 1996; Miller et al., 2008; Vigoda, 2000, 2001).

Though a few studies found the positive outcomes of organizational politics of leaders, it is typically a negative phenomenon (Drory \& Vigoda-Gadot, 2010). The political behaviours were frequently associated with manipulation, defamation, subversive activities, and illegitimate ways of overusing power (Ferris and Kacmar 1992). Ferris et al., (1989) maintained that actual politics is not a matter; instead, perceived politics is a matter, and that leads to organizational and individual consequences. In line with this, Ferris and Kacmar (1992) describe perceived organizational politics as individuals' subjective evaluations regarding the extent to which a work environment is characterized by co-workers and supervisors demonstrating self-serving behaviours.

Perceived organizational politics is related to the terms like power, cunning, manipulation or the achievement of goals in an aggressive manner (Ferries\&King, 
1991; Saad \& Elshaer, 2017). Also, a large number of studies explored the adverse consequences of perceived organizational politics on employees work-related outcomes and behaviours such as employee satisfaction, commitment, engagement, stress, turnover intention and organizational citizenship behaviour (Asrar-ul-Haq et al., 2019; Chang et al., 2009; Landells \& Albrecht, 2017, 2019; Valle \& Perrewé, 2000; Witt et al., 2002; Harris et al., 2007; Windsor, 2016). The following sections discuss the relationship between politics, satisfaction and emotional intelligence.

\subsection{Organizational politics and job satisfaction}

Job satisfaction is an employee's affective responses to specific job-related activities and is resulting from both affect and cognition (Olson \& Parayitam, 2014). Job satisfaction describes how employees feel about their job and to what extent they like it (Spector, 1997) and it is an attitude towards employees' workrelated evaluation, affect and beliefs (Weiss, 2002). Employee's satisfaction has been described from a different perspective. However, the widely accepted description of satisfaction is "a positive (or negative) evaluative judgment one makes about one's job or job situation" (Weiss, 2002; p. 175). Achievement in the workplace and close associations with their co-workers are the critical elements of job satisfaction. In high political wok environment employees are maltreated: while inner circle members are treated well, outer circle members are badly treated. Such unfavourable conditions, directly and indirectly, affect employees job, which in turn badly affect their job enjoyment. Lack of happiness in the workplace and conflict among organizational members declines positive emotional response to the work they perform.

Moreover, organizational politics tend to establish uncertainty in the workplace because performance standards and reward structures in these organizations are ambiguous (Rosen \& Hochwarter, 2014). Also in a high political environment employees perceive that people are undermining and manipulating others, razing to the ground those who are not members of their circle, allocating resources and benefits out of the rules and regulations of the organization and abusing authority. A workplace with such negative occurrences creates more worries for those within a collectivistic cultural context (Olson \& Parayitam, 2014) like Sri Lanka. 
Perceived organizational politics is related to decreased employee job satisfaction (Ferris et al., 1989; Drory, 1993). Further Drory (1993) found that organizational politics has a potentially damaging effect on low-status employees while it does not affect higher status employees. Bozeman et al. (1996) found a negative effect of perceived organizational politics on various employees work outcomes and the moderating effect of self-efficacy. They found that the relationship between organizational politics and work outcome was more substantial for the individual with low job efficacy than high self-efficacy. In a highly political environment employee's experiences low level of commitment to value high work standards, lack of organizational support for innovation, performance evaluations are ineffective, and employees are not loyal to the organization and working for only maximizing their benefits.

\subsection{EI, politics and satisfaction}

Mayer and Salovey (1997: p. 10) define emotional intelligence as "the ability to perceive accurately, appraise, and express emotions; the ability to access and/or generate feelings when they facilitate thought; the ability to understand emotions and emotional knowledge; and the ability to regulate emotions to promote emotional and intellectual growth." EI, as an ability enables individuals to motivate himself/herself and persist in the face of frustration (Goleman, 1996). EI facilitates individuals to monitors their own and others' feelings and emotions, and use them to direct their action and reaction (Mayer et al., 1990)

EI plays a crucial role in the employee's job satisfaction (Wong \& Law, 2000; Sy et al., 2006; Wolfe \& Kim 2013). EI competencies such as self-regulation selfawareness, self-motivation, social skills and empathy enable individuals to manage better the challenges they face (Goleman, 1998; 2003). According to Spector's (1997) model, both organizational and personal factors predicts employee's job satisfaction. Similarly, Hendee (2002) and Tett \&Meyer (1993) identified that Job satisfaction is determined by both environmental factor and individual personality characteristics. According to Goleman (1996), people with emotional intelligence understand and regulate theme self and others which in turn can determining the level of satisfaction. EI positively influence job satisfaction and personal and life satisfaction (Zeidner et al., 2004). However, Hosseinian et al. (2008) found no relationship between emotional intelligence and job satisfaction. 
Individual's self-awareness and self-management can facilitate them to regulate their negative feelings and emotions, and thus the individual can perform well and feel happy. Understanding others and the environment make them create a good relationship with others and see and seize the opportunity around them. Further, these characteristics help individuals to identify and use their strength and opportunity and to eliminates and overcome their weakness and threats. Previous studies suggest that EI play a moderation role in aggressive behaviours and workplace stress (Slaski \& Cartwright 2003). Nikolaou (2005) found a positive association between EI, stress and organizational commitment. Individuals with higher levels of EI were more likely or more able to engage in collaborative conflict resolution; lower EI scores were associated with less effective strategies handling conflict in a forceful way and avoidance behaviour (Jodan \& Troth, 2002). Wong (2002) found that EI was positively correlated with the follower's satisfaction and willingness to engage in extra-role behaviour.

The relationship between perceived organizational politics and employees' satisfaction can be explained through the JD-R model. In the JR-D model, job demands negatively valued physical, social, or organizational aspects of the job and required continued physical or psychological effort. (Demerouti et al., 2001). In a high political workplace, favouritism, unclear performance standards, and unfair rewards and promotions are the general features and thus perceived organizational politics can be considered as job demands. Further, perceived organizational politics hamper personal development, learning, and goal achievement; consequently, it activates negative emotions (Crawford et al., 2010). Therefore, when individuals experience a high level of perceived organizational politics, they express dissatisfaction. Emotional intelligence as a personal resource can reduce the negative effect of organizational politics on employee satisfaction. Therefore, the researcher of the current study posits the following three hypotheses:

H1: Perceived organizational politics negatively influence job satisfaction

H1: Emotional EI moderate the relationship between perceived organizational politics and satisfaction

H3: Higher EI levels causes a weaker relationship between politics and satisfaction, while lower levels of EI causes a stronger relationship between politics and satisfaction. 


\section{Research Method}

This study relied on cross-sectional and self-reported data. Cross-sectional and self-reported data is prone to common method bias (CMB). To reduce the CMB researcher has taken the following steps to in the survey design stage. The researcher informed the participants that absolute anonymity and confidentiality would be maintained, and requested the participants to "answer honestly and to the best of their knowledge". To detect CMB researcher employed Harman's onefactor assessment and the assessment disclosed that no common factor emerged or one common factor absorbed the majority of the covariance among the measures. Respondents of this study were school teachers in the northern part of Sri Lanka. Respondents were approached on researchers' convenience basis. Of the total of 500, 286 school teachers responded back. The response rate was 57.2 per cent which is greater than the average rate of 52.5 per cent in organizational research (Baruch \& Holton, 2008). Ten questionnaires were rejected because of more than $15 \%$ per indicator. Ultimately, 276 responses were data analysis (effective response rate was $55.2 \%$ )

The original items of the survey were in the English language. The survey was translated to respondents' native language (Tamil) and the researcher conducted a pilot survey to identify if there are any issues associated with the measures, questionnaire design, etc. The respondents were also assessed on some demographical characteristics such as gender, marital stage, age, work experience, and educational qualifications (Table 1) 
Table 1: Respondents' Profile

\begin{tabular}{|llcl|}
\hline Respondents' Profile & & Number (percentage) \\
\hline Gender & Male (1) & 102 & $(37)$ \\
& Female (2) & 174 & $(63)$ \\
Marital status & Married (1) & 212 & $(77)$ \\
& Single (2) & 64 & $(23)$ \\
Age & Less than 30 & 24 & $(9)$ \\
& 30- 45 & 150 & $(54)$ \\
Educational qualification & Over 45 & 102 & $(37)$ \\
& Non-graduates & 43 & $(16)$ \\
& Graduates & 149 & $(53)$ \\
& Maters & 79 & $(29)$ \\
& PhD & 5 & $(2)$ \\
Working experience & Less than 5 years & 28 & $(10)$ \\
& 5-15 Years & 136 & $(50)$ \\
& 16- 25 & 92 & $(33)$ \\
& Above 25 years & 20 & $(7)$ \\
\hline
\end{tabular}

Female participants accounted for 174 (63\%) of the respondents and male for 102 (37\%). Two hundred twenty-one teachers, accounting for 77 per cent, were married. Regarding age, although 102 (37\%) respondents had are over 45 years of age, the majority of the respondents were between the ages of 30-45. Most of the respondents accounted for 149 (53) were degree holders. Regarding working experience, fifty percent of the respondents have 6 to 15 years of work experience, and only $10 \%$ responders are with less than five years' experience. The demographic profile of the respondents shows that different category of respondents was included in the survey.

\subsection{Measures}

In the present study, multiple items are used to measure all perceptual measures. Other than the demographics questionnaire, responses to measures were gathered 
on a five-point or seven-point Likert scale. Except for the perceptual measures, all demographic variables were measured as a categorical variable shown in table 1, for example, $1=$ male, $2=$ female. All the original scales were in English, but they were translated into Tamil using a back-translation approach (Brislin, 1970).

Organizational politics: the current study used 18 items scale recently developed by Landells and Albrecht (2019). These items were designed to assess negative organizational politics across five dimensions: relationships (4 items); reputation (4 items); decisions ( 3 items); resources ( 3 items); communication ( 4 items). In the current study, perceived organizational politics has been considered as a secondorder construct, and the five dimensions were considered as the first order construct. The latent variable score of each dimension has been used as indicator's score of perceived organizational politics. Items were anchored on a five-point Likert-type scale ( $1=$ strongly disagree, $5=$ strongly agree). Reported internal consistency reliability of the scale in the previous study (Landells Albrecht, 2019) and the current study was satisfactory.

Emotional Intelligence (EI): Wong and Law's Emotional Intelligence Scale (WLEIS) with 16 items (Wong \& Law 2002) was employed to measure EI. This scale asses EI through four dimensions: self-emotion appraisal (SEA), othersemotion appraisal (OEA), use of emotion (UOE), and regulation of emotion (ROE). These four dimensions of EI have been considered as low order constructs, and EI has been considered as high order in this study. Therefore, the score of the latent variable of each component has been used as indicator's score of EI. Items were anchored on a seven-point Likert-type scale $(1=$ strongly disagree, $7=$ strongly agree). Reported internal consistency reliability of the scale in the previous study (Wong \& Law, 2002) and the current study was satisfactory.

Job Satisfaction: In this study, five items job satisfaction scale developed by Brayfield and Roth (1951) called a Job satisfaction Inventory has been used to measure repatriates job satisfaction. Despite the age of this measure, it has still been used widely in recent literature and obtained acceptable reliability value (Cronbach's Alpha $>0.7$ ). The scale for these questions ranged from $1=$ strongly disagree to $5=$ strongly agree, and participants are requested to rate these items on this scale. Sample items were: "I feel fairly well satisfied with my present job" 
"most days I am enthusiastic about my work" "I find real enjoyment in my work". Reported internal consistency reliability of the scale in the current study was satisfactory (Cronbach's Alpha $=0.85)$.

\subsection{Dataanalysis procedure}

First, the data were cleaned, and normality was ensured. Consequently, exploratory factor analysis (EFA) was performed to identify if the same factor structures, as found before, were replicated, or if new factors emerged other than those anticipated in this study. EFA, as expected, found the three-factor model with Eigenvalues higher than 1.0. Following the EFA reliability and validity of the constructs were assessed through widely accepted criteria (Hair et al., 2011, 2017). Finally, the hypothesized relationships were tested through structural equation modelling with Smart PLS.

\section{Data Analysis}

\section{Reliability and validity of the constructs}

After confirming the factor structure reliability of each construct was assessed through Cranach's alpha and composite reliability (CR) and the value of Cranach's alpha and CR were more generous than the expected value of 0.7 (Table 2) which confirms the reliability of the construct (Hair et al., 2013, 17).

Table 2: Reliability and validity of the constructs

\begin{tabular}{|c|c|c|c|}
\hline \multirow{2}{*}{ Constructs } & Cronbach's & Composite & Average Variance \\
\hline & Alpha & Reliability (CR) & Extracted (AVE) \\
\hline Emotional Intelligence (EI) & I) 0.847 & 0.895 & 0.683 \\
\hline Politics (POL) & 0.896 & 0.920 & 0.660 \\
\hline Satisfaction (SAT) & 0.877 & 0.912 & 0.675 \\
\hline
\end{tabular}

The convergent validity was assessed through average variance extracted (AVE), AVE of each construct was above the expected value of 0.50 that indicating the existence of adequate convergent validity (Hair et al., 2011, 13). Discriminant validity was assessed through Fornell and Larcker criteria and Heteroraitmonotrait(HTMT) ratio. 
Table 3: Fornell - Larcker Criterion

\begin{tabular}{lccc}
\hline \multicolumn{1}{c}{ Constructs } & EI & Politics & SAT \\
\hline EI & $\mathbf{0 . 8 2 6}$ & & \\
Politics & -0.164 & $\mathbf{0 . 8 1 2}$ & \\
SAT & 0.259 & -0.588 & $\mathbf{0 . 8 2 2}$ \\
\hline
\end{tabular}

The square root of AVE was higher than inter-construct correlations (Fornell \& Larcker, 1981) (Table 3). Moreover, the Heterorait-monotrait (HTMT) ratio for all pair of constructs was less than the maximum limit of 0.85 , and its bootstrap confidence interval value does not include 1 (Henseler et al., 2015). These two statistics ensured the existence of adequate discriminant validity among the measurement model as a whole (Fornell \& Larcker, 1981; Hair et al., 2011, 2017, Henseler et al., 2015).

After confirming the reliability and validity of the measurement model, hypotheses were tested through structural equation modelling with Smart PLS. Path coefficient and its significance (in bracket) are shown in figure 1

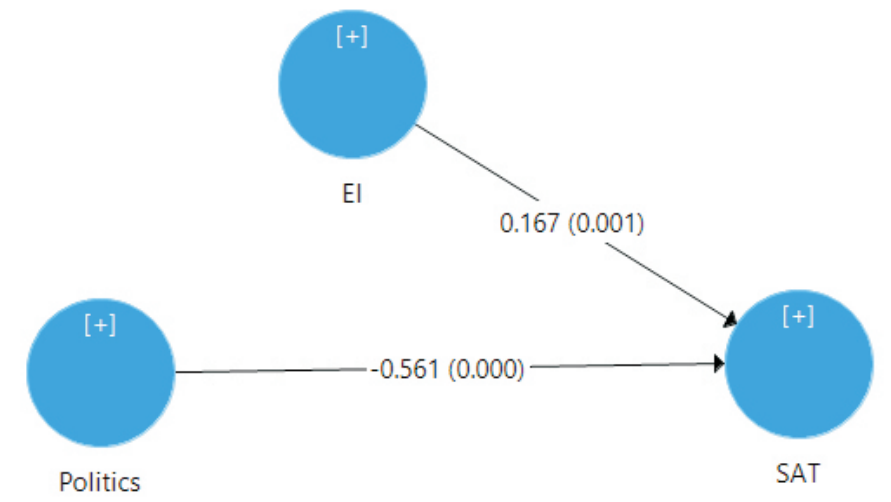

Figure 1: Path coefficient and its significance (in bracket)

Results show that while perceived organizational politics is negatively related to satisfaction $(\beta=-0.516, p=0.000)$ EI positively related to satisfaction $(\beta=0.167$, $p=0.001)$. The higher the perceived organizational politics, the lower the job satisfaction. Organizational politics as a negative stressor can reduce teacher's satisfaction. Employees with high emotional intelligence are highly satisfied.

The researcher assessed the effect of EI on the relationship between perceived politics and satisfaction via PLS-SEM, and the results are shown in figure 2. 


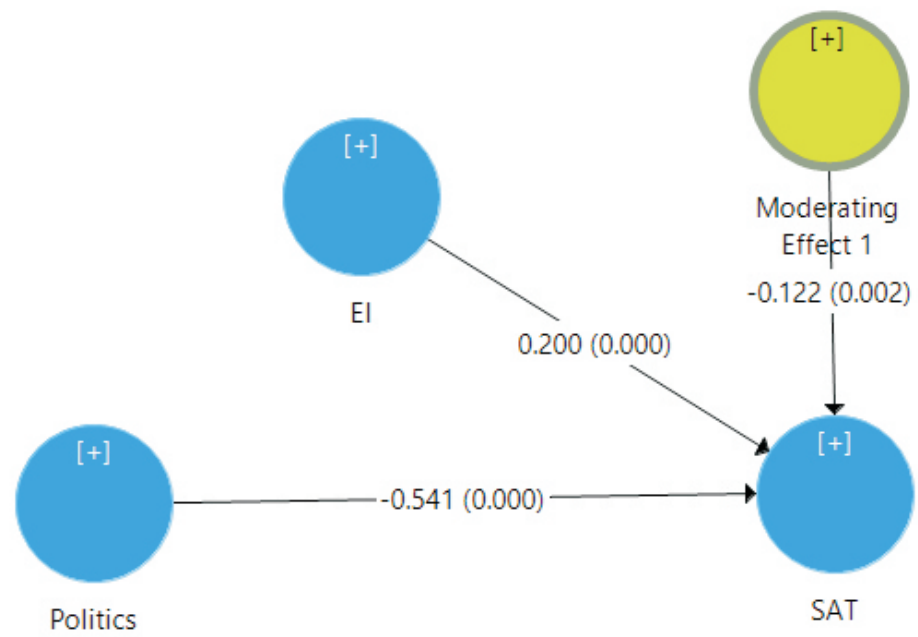

Figure 2: Path coefficient and its significance with the moderator effect

The interaction term was -0.122 , and the simple effect of politics on satisfaction is -0.541 . Therefore, the relationship between politics and satisfaction is -0.541 for an average level of EI. The results demonstrate that when emotional intelligence increased by one standard deviation unit, the relationship between politics and satisfaction decrees by the size of the interaction term (0.122) On the contrary, when EI reduced by one standard deviation point, the relationship between politics and satisfaction increases by the size of the interaction term $(0.122)$

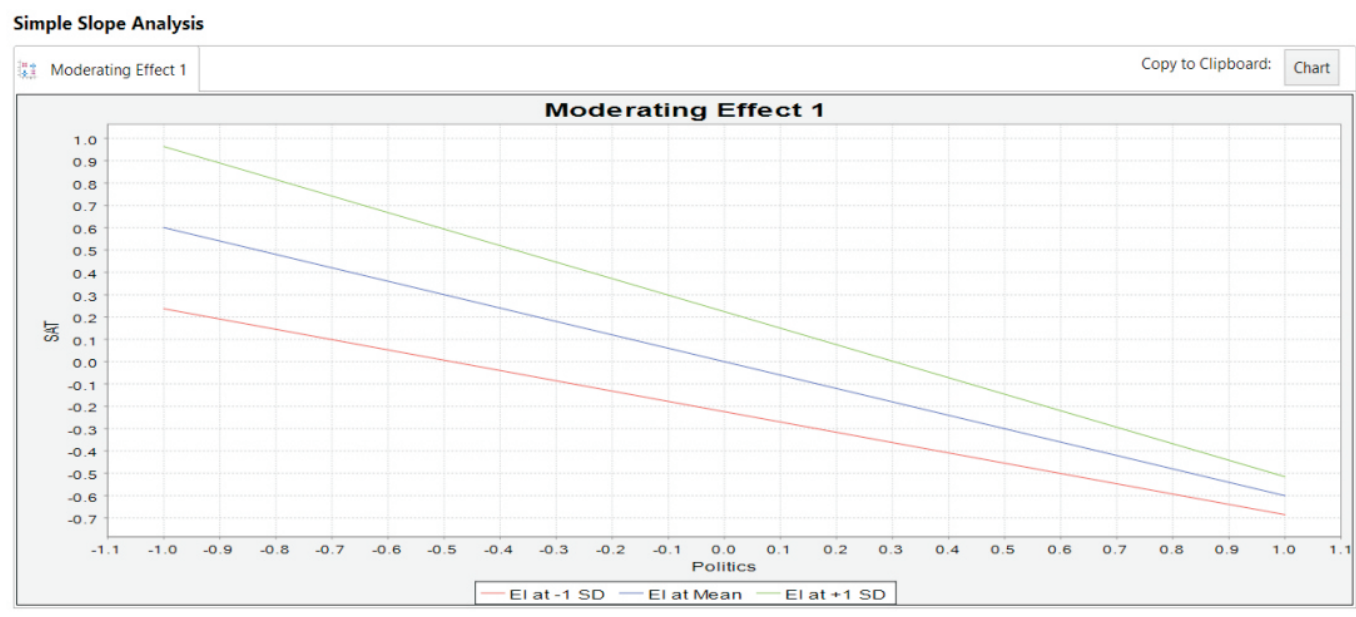

\section{Figure 3: Moderating effect_Simple slop Analysis}

Simple slope analysis produced by PLS-SEM (see figure 3) shows that higher EI level entails a weaker relationship between politics and satisfaction, while lower levels of EI lead to a stronger relationship between politics and satisfaction. 


\section{Discussion}

This study investigated the influence of perceived organizational support on satisfaction with EI as a moderator on this relationship among school teachers. Along with the findings of the previous studies (Wong \& Law, 2000; Sy et al., 2006; Wolfe \& Kim, 2013), this study explored that perceived-organizational politics has a significant and negative impact on satisfaction. As expected EI positively influenced on satisfaction. Teachers with a high level of perceivedorganizational politics experience low satisfaction, and teachers with a low level of perceived organizational politics experience a high level of satisfaction. Also, teachers with high EI low EI experience high and low satisfaction, respectively. Further, this study disclosed that emotional intelligence moderate the relationship between perceived politics and satisfaction. The results show that higher EI levels lead to a weaker relationship between politics and satisfaction, while lower levels of EI leads to a stronger relationship between politics and satisfaction.

Teachers with high EI are highly satisfied than with low EI at a high level of perceived politic. It implies that teachers with low emotional intelligence adversely affected by perceptions of politics than with high emotional intelligence. According to Jordan and Troth (2002), individuals with a high level of EI were more able to engage in collaborative conflict resolution. In a high political workplace, organizational members engage in bypassing authority lines, hiding valuable information, using pressure tactics and unethical way to maximize their personal gain consequently employees are frustrated and dissatisfied with the work and the work environment. Employees with high emotional intelligence can monitor their own and others' feelings and emotions and use them to guides their thinking and actions (Mayer et al., 2000). Also, they can motivate themself and persist in the face of frustration, to regulates their moods and keep distressed from swamping the ability to think, empathies and to hope (Goleman, 1995; Goleman, 1998; 2003). Therefore, employees with high EI can manage themselves in the political environment and able to maintain their attitude (satisfaction) stably. Employees with low emotional intelligence find difficulties to hope with the ambiguity and uncertainty created by organizational politics and thus experiences a low level of satisfaction. 
Further, the findings of the study can be explained through JD-R model. The general features organizational politics, such as favouritism, unclear performance standards, and unfair rewards and promotions can be considered as job demands, can activate negative emotions. Therefore, when individuals experience a high level of perceived organizational politics, they express dissatisfaction. Emotional intelligence as a personal resource can reduce the negative effect of organizational politics on employee satisfaction.

\section{Contribution of the study}

This study contributes to both literature and practice. Although the relationship between perceived politics and satisfaction has been well documented among employees in business organizations, there is a lack of study that investigate this relationship among academic organizations, particularly among teachers in Sri Lankan schools. Further, previous studies have assessed many individual-level variables such as commitment (Hochwarter et al., 1999), self-efficacy (Bozeman et al., 2001), political behaviour (Harrell-Cook et al., 1999) and negative and positive affect (Hochwarter \& Treadway, 2003) as a moderator on the relationship between politics and satisfaction but no study investigate the EI as a moderator on this relationship. This study extends the literature by investigating the politics and satisfaction relationship among school teachers and investigating the role of EI on this relationship. Further, this study deepening the understanding of the relationship between perceived politics and satisfaction.

The finding of the study helps school administrators and teachers to understand the negative effect of perceived organizational politics. The findings of this study highlight the importance of preventing or minimizing organizational politic because lack of employees satisfaction badly affects both the organization and the employees. The organization must take necessary steps to reduce perceived organizational politics of employees to avoid the harmful consequences of such perceptions. Faire employee treatment, adapting existing rules, policies and procedures, being transparent in all activities and adopting no nepotism policy in implementing Human Resource activities are the means to reduce organizational politics. Employees also need to take attempt to reduce the negative effect of perceived politics by developing their skills, capabilities and abilities to overcome 
issues emerged from organizational politics. The findings of the study suggest that teachers also take the necessary steps to overcome the negative consequences of organizational politics by enhancing their EI competencies/skilles. Further, as EI has been positively related to positive individual and organizational level outcomes (Goleman, 1998; 2003; Salminen \& Ravaja, 2017; Wolfe \& Kim 2013; Zeidner et al., 2004), both the organization and individuals should take necessary steps to enhance the EI. Individuals can enhance their EI by improving active listing, self-motivation, and skill of empathy through continuous practice. Organizations can facilitate employees to develop their EI by providing welldesigned continued training.

\section{Directions for Further Research}

This study suggests several avenues for further research. Further studies can be directed to investigate the factors influencing perceived organizational politics. This study was conducted among school teachers; further study needs to be conducted in a different context to generalize the findings. As the research design of this study was cross-sectional, it is impossible to infer a causal relationship. A greater focus on longitudinal research designs may give a better indication of politics perception and satisfaction. Also, further investigations are needed to compare the influence of organizational politics and perceived organizational politics on individual and organizational level variables. Recent studies explored that some individuals perceive that organizational politics leads to positive outcomes. However, these are in an infant state; further studies are needed to confirm the positive outcomes of the organizational politics and who experiences the positive side of organizational politics. 


\section{References:}

Akanbi, P. A., \& Ofoegbu, O. E. (2013). Influence of perception of organizational politics on job satisfaction among university workers in Oyo Town, Nigeria. European Journal of Business and management, 5(2), 162-168.

Albrecht, S. L., \& Marty, A. (2017). Personality, self-efficacy and job resources and their associations with employee engagement, affective commitment and turnover intentions. The International Journal of Human Resource Management, 1-25, https://doi.org/10.1080/09585192.2017.1362660

Arefin, M.S., Alam, M.S., Li, S.L. \& Long, L., (2020). Spillover effects of organizational politics on family satisfaction: the role of work-to-family conflict and family support.Personnel Review. DOI 10.1108/PR-02-20200107

Atinc, G., Darrat, M., Fuller, B. \& Parker, B.W. (2010). Perceptions of organisational politics: A meta-analysis of theoretical antecedents", Journal of Managerial Issues, 22 (4) pp. 494-513

Bakker, A. B. \& Demerouti, E. (2007). The job demands-resources model: state of the art, J. Manag. Psychol, Vol. 22, pp. 309-328.

Bakker, A. B., \& Demerouti, E. (2014). Job demands-resources theory, in Wellbeing: A Complete Reference Guide, Work and Well-being, eds P. Y. Chen and C. L. Cooper (New York, NY: Wiley Blackwell), 37-64.

Bergeron, D.M. \&Thompson, P.S. (2020). Speaking Up at Work: The Role of Perceived Organizational Support in Explaining the Relationship Between Perceptions of Organizational Politics and Voice Behavior. The Journal of Applied Behavioral Science, Vol.52 No.2, pp.195-215.

Blömeke, S., Houang, R., Hsieh, F. J., \& Wang, T. Y. (2017). Effects of job motives, teacher knowledge and school context on beginning teachers' commitment to stay in the profession: A longitudinal study in Germany, Taiwan and the United States. In G. K.

Bozeman, D. P., Hochwarier, W. A., Perrewe, P. L., \& Brymer, R. A. (2001). Organizational Politics, Perceived Control, and Work Outcomes: Boundary 
Conditions on the Effects of Politics 1. Journal of Applied Social Psychology, $31(3), 486-503$.

Bozeman, D. P., Perrewe, P. L., Kacmar, K. M., Hochwarter, W. A., \& Brymer, R. A. (1996). An examination of reactions to perceptions of organizational politics. Paper presented at the 1996 Southern Management Association Meetings, New Orleans.

Brayfield, A. H., \& Rothe, H. F. (1951). An index of job satisfaction. Journal of applied psychology, 35(5), 307.

Chang, C. H., Rosen, C. C., \& Levy, P. E. (2009). The relationship between perceptions of organizational politics and employee attitudes, strain, and behavior: A meta-analytic examination. Academy of Management Journal, 52(4), 779-801.

Christiansen, N., Villanova, P., \& Mikulay, S. (1997). Political influence compatibility: Fitting the person to the climate. Journal of Organizational Behavior: The International Journal of Industrial, Occupational and Organizational Psychology and Behavior, 18(6), 709-730.

Crawford ER, JA LePine, \& BL Rich (2010) Linking job demands and resources to employee engagement and burnout: a theoretical extension and metaanalytic test. Journal of Applied Psychology, 95(5), 834-848.

Cropanzano, R., Howes, J. C., Grandey, A. A., \& Toth, P. (1997). The relationship of organizational politics and support to work behaviors, attitudes, and stress. Journal of Organizational Behavior: The International Journal of Industrial, Occupational and Organizational Psychology and Behavior, 18(2), 159-180.

Demerouti E, AB Bakker, F Nachreiner \& WB Schaufeli (2001). The job demands-resources model of burnout. Journal of Applied Psychology 86(3), 499-512.

Drory, A. (1993), "Perceived political climate and job attitudes", Organization Studies, Vol. 14, pp. 59-71.

Ferris, G. R., \& Judge, T. A. (1991). Personnel/human resources management: A political influence perspective. Journal of management, 17(2), 447-488. 
Ferris, G. R., Adams, G., Kolodinsky, R. W., Hochwarter, W. A., \& Ammeter, A. P. (2002). Perceptions of organizational politics: Theory and research directions. Research in multi-level issues, 1, 179-254.

Ferris, G. R., Frink, D. D., Galang, M. C., Zhou, J., Kacmar, K. M., \& Howard, J. L. (1996). Perceptions of organizational politics: Prediction, stress-related implications, and outcomes. Human relations, 49(2), 233-266.

Ferris, G. R., Frink, D. D., Gilmore, D. C., \& Kacmar, K. M. (1994). Understanding as an antidote for the dysfunctional consequences of organizational politics as a stressor 1. Journal of Applied Social Psychology, 24(13), 1204-1220.

Ferris, G. R., Russ, G. S., \& Fandt, P. M. (1989). Politics in organizations. Lawrence Erlbaum Associates, Inc.

Ferris, G.R. and Kacmar, K.M., 1992. Perceptions of organizational politics. Journal of management, Vol.18 No.1, pp.93-116.

Ferris, G.R., Russ, G.S. and Fandt, P.M. (1989) 'Politics in organisations', in R.A. Giacalone and P. Rosenfeld (eds) Impression management in the organisation, Hillsdale, NJ: Lawrence Erlbaum: 143-70.

Fornell, C., \& Larcker, D. F. (1981). Evaluating structural equation models with unobservable variables and measurement error. Journal of marketing research, 18(1), 39-50.

Goleman, D. (1995). Emotional intelligence: Why it can matter more than IQ', New York: Bantam Harter, JK, Schmidt, FL, \& Hayes, T. L 2002,'Businessunit-level relationship between employee satisfaction, employee engagement, and business outcomes: A meta-analysis'. Journal of Applied Psychology, 87(2), 268-279.

Goleman, D. (1998). Working with emotional intelligence. New York, NY

Goleman, D. (2001). An EI-based theory of performance. The emotionally intelligent workplace: How to select for, measure, and improve emotional intelligence in individuals, groups, and organizations, 1, 27-44. 
Guo, Y., Kang, H., Shao, B., \& Halvorsen, B. (2019), "Organisational politics as a blindfold: Employee work engagement is negatively related to supervisorrated work outcomes when organisational politics is high", Personnel Review, Vol. 48 No 3, pp. 784-798.

Hair, J. F., Hult, G. T. M., Ringle, C. M. and Sarstedt, M. (2017), A Primer on Partial Least Squares Structural Equation Modeling. 2nd Ed. Thousand Oaks: Sage.

Hair, J. F., Ringle, C. M., \& Sarstedt, M. (2011). PLS-SEM: Indeed a silver bullet. Journal of Marketing theory and Practice, 19(2), 139-152.

Hair, J. F., Ringle, C. M., \& Sarstedt, M. (2013). Partial least squares structural equation modeling: Rigorous applications, better results and higher acceptance. Long range planning, 46(1-2), 1-12.

Harrell-Cook, G., Ferris, G. R., \& Dulebohn, J. H. (1999). Political behaviors as moderators of the perceptions of organizational politics-work outcomes relationships. Journal of Organizational Behavior, 20(7), 1093-1105.

Harris, R. B., Harris, K. J., \& Harvey, P. (2007). A test of competing models of the relationships among perceptions of organizational politics, perceived organizational support, and individual outcomes. The Journal of social psychology, 147(6), 631-656.

Henseler, J., \& Fassott, G. (2010). "Testing moderating effects in PLS path models: An illustration of available procedures". In Handbook of Partial Least Squares (pp. 713-735). Springer Berlin Heidelberg.

Henseler, J., Ringle, C. M., \& Sarstedt, M. (2015). A new criterion for assessing discriminant validity in variance-based structural equation modeling. Journal of the academy of marketing science, 43(1), 115-135.

Hochwarter, W. A., \& Treadway, D. C. (2003). The interactive effects of negative and positive affect on the politics perceptions-job satisfaction relationship. Journal of Management, 29(4), 551-567.

Hochwarter, W. A., Perrewé, P. L., Ferris, G. R., \& Guercio, R. (1999). Commitment as an antidote to the tension and turnover consequences of organizational politics. Journal of vocational behavior, 55(3), 277-297. 
Hochwarter, W. A., Rosen, C. C., Jordan, S. L., Ferris, G. R., Ejaz, A., \& Maher, L. P. (2020). Perceptions of organizational politics research: past, present, and future. Journal of Management, https://doi.org/10.1177/0149206319898506

Hosseinian. S, Yazdi. S, Shaghayegh Zahraie. S and Ali Fathi-Ashtiani. A (2008) Emotional Intelligence and Job Satisfaction. Journal of Applied Sciences, 8: 903-906.

Jordan, P. J., \& Troth, A. C. (2002). Emotional intelligence and conflict resolution: Implications for human resource development. Advances in developing human resources, 4(1), 62-79.

Kacmar, K. M., \& Baron, R. A. (1999). Organizational politics. Research in human resources management, 1, 1-39.

Khattak, M.N. and O'Connor, P. (2020), "The interplay between servant leadership and organizational politics", Personnel Review, Vol. ahead-ofprint No. ahead-of-print. https://doi.org/10.1108/PR-03-2020-0131

Klassen, R. M., \& Chiu, M. M. (2011). The occupational commitment and intention to quit of practicing and pre-service teachers: Infiuence of selfefficacy, job stress, and teaching context. Contemporary Educational Psychology, 36(2), 114-129.

Landells, E. M., \& Albrecht, S. L. (2019). Perceived organizational politics, engagement and stress: The mediating influence of meaningful work. Frontiers in psychology, 10, 1612.

Lasswell, H. D (1936), Politics: Who Gets What, When, How. New York: Peter Smith.

Lasswell, H. D. (2018). Politics: Who gets what, when, how. Pickle Partners Publishing.

Li, E. Y., Olson, B., Bao, Y., \& Parayitam, S. (2014). Political behavior, trustworthiness, job satisfaction, and commitment. Chinese Management Studies.

Liang, G., \& Akiba, M. (2017). Teachers' working conditions: A cross-national analysis using the OECD 
TALIS and PISA data. In G. K. LeTendre \& M. Akiba (Eds.), International handbook of teacher quality and policy (pp. 388-402). London: Routledge.

Mayer, J. D., Salovey, P., \& Caruso, D. R. (2000). Emotional intelligence as zeitgeist, as personality, and as a mental ability.

Miller, B. K., Rutherford, M. A., \& Kolodinsky, R. W. (2008). Perceptions of organizational politics: A meta-analysis of outcomes. Journal of Business and Psychology, 22(3), 209-222.

Pfeffer, J. (1992). Managing with Power (Harvard Business School Press, Boston, MA).

Podsakoff, P. M., MacKenzie, S. B., Lee, J. Y., \& Podsakoff, N. P. (2003). Common method biases in behavioral research: a critical review of the literature and recommended remedies. Journal of applied psychology, 88(5), 879.

Rosen, C. C., \& Hochwarter, W. A. (2014). Looking back and falling further behind: The moderating role of rumination on the relationship between organizational politics and employee attitudes, well-being, and performance. Organizational Behavior and Human Decision Processes, 124(2), 177-189.

Saad, S. K., \& Elshaer, I. A. (2017). Organizational politics and validity of layoff decisions: Mediating role of distributive justice of performance appraisal. Journal of Hospitality Marketing \& Management, 26(8), 805-828.

Salminen, M., \& Ravaja, N. (2017). The positive effects of trait emotional intelligence during a performance review discussion-A psychophysiological study. Frontiers in psychology, 8, 463.

Slaski, M., \& Cartwright, S. (2003). Emotional intelligence training and its implications for stress, health and performance. Stress and health, 19(4), 233239.

Spector, P. E. (1997). Job satisfaction: Application, assessment, causes, and consequences (Vol. 3). Sage publications.

Sy, T., Tram, S., \& O'hara, L. A. (2006). Relation of employee and manager emotional intelligence to job satisfaction and performance. Journal of vocational behavior, 68(3), 461-473. 
Tett, R. P., \& Meyer, J. P. (1993). Job satisfaction, organizational commitment, turnover intention, and turnover: path analyses based on meta-analytic findings. Personnel psychology, 46(2), 259-293.

Valle, M., \& Perrewe, P. L. (2000). Do politics perceptions relate to political behaviorsfi Tests of an implicit assumption and expanded model. Human relations, 53(3), 359-386.

Vigoda, E. (2000). Organizational politics, job attitudes, and work outcomes: Exploration and implications for the public sector. Journal of vocational Behavior, 57(3), 326-347.

Vigoda, E. (2001). Reactions to organizational politics: A cross-cultural examination in Israel and Britain. Human Relations, 54(11), 1483-1518.

Vigoda-Gadot, E., \& Talmud, I. (2010). Organizational politics and job outcomes: The moderating effect of trust and social support. Journal of Applied Social Psychology, 40(11), 2829-2861.

Weiss, H. M. (2002). Deconstructing job satisfaction: Separating evaluations, beliefs and affective experiences. Human resource management review, 12(2), 173-194.

Witt, L. A., Andrews, M. C., \& Kacmar, K. M. (2000). The role of participation in decision-making in the organizational politics-job satisfaction relationship. Human Relations, 53(3), 341-358.

Wolfe, K., \& Kim, H. J. (2013). Emotional intelligence, job satisfaction, and job tenure among hotel managers. Journal of Human Resources in Hospitality \& Tourism, 12(2), 175-191.

Wong, C. S., \& Law, K. S. (2002). The effects of leader and follower emotional intelligence on performance and attitude: An exploratory study. The leadership quarterly, 13(3), 243-274.

Yusof, J. M., Zulkiffli, S. N. A., Padlee, S. F., \& Yusof, N. A. (2018). The Relationship between Organizational Politics, Job Satisfaction and Turnover Intention in the Maritime-Related Agencies in the East Coast of Peninsular Malaysia. KnE Social Sciences, 1001-1013. 